Abstracta Iranica Iranica

Revue bibliographique pour le domaine irano-aryen

Volume 32-33 | 2013

Comptes rendus des publications de 2009-2010

\title{
Moya Carey. Al-Sufi and son: Ibn al-Sufi's poem on the stars and its prose parent
}

\section{Nourane Ben Azzouna}

\section{(2) OpenEdition}

1 Journals

\section{Édition électronique}

URL : http://journals.openedition.org/abstractairanica/40793

DOI : 10.4000/abstractairanica.40793

ISSN : 1961-960X

Éditeur :

CNRS (UMR 7528 Mondes iraniens et indiens), Éditions de l'IFRI

\section{Édition imprimée}

Date de publication : 1 décembre 2013

ISSN : 0240-8910

Référence électronique

Nourane Ben Azzouna, « Moya Carey. Al-Sufi and son: Ibn al-Sufi's poem on the stars and its prose parent », Abstracta Iranica [En ligne], Volume 32-33 | 2013, document 303, mis en ligne le 01 juillet 2016, consulté le 26 septembre 2020. URL : http://journals.openedition.org/abstractairanica/40793 ; DOI : https://doi.org/10.4000/abstractairanica.40793

Ce document a été généré automatiquement le 26 septembre 2020.

Tous droits réservés 
Moya Carey. Al-Sufi and son: Ibn alSufi's poem on the stars and its prose parent

Nourane Ben Azzouna 


\section{RÉFÉRENCE}

Moya Carey. « Al-Sufi and son: Ibn al-Sufi's poem on the stars and its prose parent ». Muqarnas, 26, 2009, p. 181-204.

Cet article porte sur une sélection versifiée et illustrée du célèbre traité des étoiles fixes de 'Abd al-Raḥmān al-Ṣūīi (m. 986), très vraisemblablement composée par son fils Abū 'Alī Ḥusayn, à Rayy, dans la première moitié du $\mathrm{XI}^{\mathrm{e}} \mathrm{s}$. Bien que beaucoup moins connue que le traité d'al-Ṣūfī, cette sélection, également en arabe, d'Ibn al-Ṣūfī a néanmoins eu du succès puisqu'elle est conservée dans pas moins de dix-huit copies. L'A. porte son attention sur l'une des plus anciennes et des plus belles de ces copies (Téhéran, bibliothèque Reḍā 'Abbāsī, M. 570), vraisemblablement antérieure à 554/1159-60 (date qui apparaît dans une note) et richement ornée, avec une šamsa, un double portrait d'auteur et quarante et une illustrations. Moya Carey tente d'abord de reconstituer la biographie d'Ibn al-Ṣūfī. Elle compare ensuite le texte et les illustrations du traité d'origine et de sa sélection versifiée par Ibn al-Ṣūfī et souligne la valeur mnémotechnique du poème qui était probablement destiné à être mémorisé et utilisé dans l'obscurité de la nuit, comme outil pour identifier les constellations classiques et apprendre leurs correspondances arabes. Elle finit par une discussion sur le double portrait qu'elle identifie de manière convaincante comme celui d'al-Ṣūfī et d'Ibn al-Ṣūfī, autrement dit le père et le fils, le maître et le disciple, l'auteur et l'interprète, soulignant la valeur trans-générationnelle de la conception de la transmission du savoir à cette époque.

\section{AUTEURS}

\section{NOURANE BEN AZZOUNA}

Agence France Muséums-Louvre, Abu Dhabi 